\title{
Consumer Ethnocentrism in 21st Century: A Review and Research Agenda
}

\section{Sheeraz Tantray*}

Department of Business Administration, Central University of Jammu, India

\begin{abstract}
Owing to the Industrial revolution, fading communist era and the relative convergence of economic ideologies across the globe as a consequence of liberalization and globalization leading to exponential growth in the world trade, formal tariff barriers have been reduced considerably. In such circumstances, if projected inclusively, the thrust for exploring informal tariff barriers can be beneficial for retaining the home market base besides attracting consumers from outer groups This new 'forms of protectionism' of the national businesses, called 'cross-currents' of globalization to dilute the international competition are emerging to discourage international competition and consumer ethnocentrism is one such non-tariff barrier. Researchers have explored the possibilities of reviving the segmentation and positioning strategies by employing ethnocentrism as a strategic tool. The objective of this paper is to explore the body of knowledge and literature gap confronting the subject area of consumer ethnocentrism and to deliberate upon the antecedents and consequences of the consumer ethnocentrism besides the roles of mediating and moderating variables.
\end{abstract}

The paper presents the integrative framework and comprehensive summary tables with wide deliberations providing holistic view of consumer ethnocentrism in globalized world. Besides enriching the marketing knowledge, the paper also offers broad avenues for further research.

Keywords: Ethnocentrism; Consumer behaviour; Socialization; Mediators; Moderators

\section{Introduction}

Owing to the Industrial revolution and fading Communist era, the relative convergence of economic ideologies across the globe as a consequence of liberalization and globalization have led the exponential growth in the world trade. Jeannet and Hennesy [1] contended that informal tariff barriers will be having a wide scope although formal tariff barriers are going to be reduced considerably in the coming decade. In an attempt to achieve uniform product related regulations there has been a shift in the focus of international trade negotiations between countries and regional blocs. The new 'forms of protectionism' of the national businesses, called 'cross-currents' of globalization by the Porter [2], to dilute the international competition are emerging to discourage international competition and consumer ethnocentrism is one such non-tariff barrier. As stated by Sharma et al. [3] consumer ethnocentrism is "the beliefs held by [...] consumers about the appropriateness, indeed morality, of purchasing foreign-made products irrespective of the quality or price considerations, purely on nationalist feelings". Consumer ethnocentrism can unduly made to favour the domestic companies by institutionalizing it in the procurement policy of the government informally [4] or widespread mainly as the tendencies of consumers to favour 'home country' products [5].

The objective of this paper is to explore the body of knowledge and literature gap confronting the subject area of consumer ethnocentrism and to deliberate upon the antecedents and consequences of the consumer ethnocentrism besides the roles of mediating and moderating variables.

\section{Consumer Ethnocentrism: Then and Now}

The concept of consumer ethnocentrism has been the centre of scholarly enquiry from the past few decades. The roots of the concept can be traced to the sociological concept of ethnocentrism introduced by Sumner [6] in 1906 and has defined it as "the view of things in which one's own group is the center of everything, and all others are scaled and rated with reference to it. [...] Each group nourishes its own pride and vanity, boasts itself superior, exalts its own divinities, and looks with contempt on outsiders". Ethnocentrism is a global phenomenon found in all social groups, religious groups, families and nations [7]. Among the members of a particular group, the ethnocentrism leads to an increase in group conformity and loyalty and highly depends upon the nature of social group, pride, prejudice and racial discrimination [8]. Consumer ethnocentrism was developed as a distinct concept in the field of marketing by Shimp and Sharma [5] in 1987, representing mainly the tendencies of consumers to favour 'made in country' products rather than 'made in foreign'. Having a purely sociological origin it was transformed into a psychological construct with relevance to both individual-level personality systems and socio-cultural frameworks [5]. Almost all previous researchers have relied heavily on the literature of ethnocentrism in exploring on the antecedents of the CET [9-12]. Lewis argued that ethnocentrism is deep rooted universal phenomenon pertaining to intergroup relations while Lynn [13] contended that ethnocentrism is a part of human nature. Barger [8] further emphasized that the concept of ethnocentrism is more connected to the learning and attitudes of the people. Thus, the concept of ethnocentrism is obviously related to the concepts of psychology. However, ethnocentrism can be discussed from the biological perspective as well. According to Dreu et al. [14], human ethnocentrism is modulated by brain oxytocin. Brain oxytocin, also known as hormone of love is generated from the hypothalamus region of the human brain and makes collaborations among in-group members by making people trust each other. Hence this oxytocin hormone may create a feeling in the human mind to think of his/her own group as superior to other groups [14].

*Corresponding author: Tantray S, Department of Business Administration, Centra University of Jammu, India, Tel: +91-7006961190; E-mail: satantray@gmail.com

Received May 30, 2018; Accepted August 17, 2018; Published August 24, 2018

Citation: Tantray S (2018) Consumer Ethnocentrism in 21st Century: A Review and Research Agenda. Bus Eco J 9: 368. doi: 10.4172/2151-6219.1000368

Copyright: (C) 2018 Tantray S. This is an open-access article distributed under the terms of the Creative Commons Attribution License, which permits unrestricted use, distribution, and reproduction in any medium, provided the original author and source are credited. 
For the purpose of marketing implications, the concept of CET was formulated by Shimp and Sharma [5] as 'domain specific subject' in consumer behaviour and was described as the tendency of the consumers to distinguish between products of out-groups (made in foreign) and the in-groups (home country) purely on the nationalist reasons irrespective of the quality, price or desired features of the products concerned. The perception of losses to the domestic country in terms of wealth drain, loss of employment and heightened competition for domestic products thrusts a moral responsibility on in favouring home made products [15-18]. It is worth mentioning here that research regarding the consumers temperament to choose between in-groups and out-groups has been documented by Anderson and Cunningham [19] and Dornoff et al. [20] even before Shimp and Sharma [5]. With the changing marketing scenario and the stiff competition among developing and developed countries, the CET is becoming a ply card in the hands of marketers to influence the consumers from either side. The various elaborations on the specific properties of CET have been put forward by Sharma et al. [3]. First, CET is not a specific attitude but the aggregation of general tendencies towards 'in-group love'. Second, it has greater tendency of inelasticity with respect to other products or price tags. Third, it is a result of perceived concern of individuals for their own country as opposed to negative effects of imports for nation especially plight of nationals in respect of loss of employment. Finally, Crawford and Lamb [21] contended that CET is also applicable in industrial goods also and is not limited to the domestic or consumer goods only.

It is important to mention the difference between CET and 'country-of-origin bias' as the two are completely distinct, a fact that is often misunderstood. The former is a general tendency to avoid buying foreign products irrespective of the country of origin (COO) image [22]. Thus an Indian consumer can favourably perceive the country of origin effect for Korean mobile due to its quality attribute but decide not to buy it due to its nationalist reasons. Olsen et al. [23] argued that consumers rely on the cues of COO only when the necessary information is lacking regarding the products. From the studies on $\mathrm{COO}$ and CET with respective to buying behaviour, it can be argued that CET represents the normative and affective while as COO symbolizes affective and cognitive aspects of consumer buying behaviour. The CET is mainly influenced by the normative pressure that consumers observe for not to buy the foreign made products.

To assess the ethnocentric tendencies of the consumers, the predominant measurement instrument used is the 17 item CET Scale, developed by Shimp and Sharma [5] in relation to purchase of domestic or foreign products. The scale was originally developed and validated in the United States; thereafter the cross national validity of CET Scale was carried out by researchers across different countries. For instance, Netemeyer et al. [24] replicated the Shimp and Sharma's study with respondents from United States, France, Japan and West Germany; Balabanis et al. [25,26] carried similar research in Turkey in 2001 and by Klein in Russian and china in 2006. All the findings have strongly supported the uni-dimensional factor structure of the CETSCALE as suggested by Shimp and Sharma [5] and it is the strong ground to claim that CETSCALE has got cross national reliability and validity; the same has been confirmed by Durvasula et al. [27], Hult et al. [28] and LuqueMartinez et al. [29].

Organizations are facing stiff competition due to globalization, at the same time investment in foreign markets is increasing significantly [30]. Recently, owing to the technical and communication developments global marketing activities have increased astonishingly
[31]. Consumers' bias towards their national products is a significant determinant of local product purchase behaviour [32]. By exploring attitudes of consumers towards domestic and foreign products, local and global marketers can take significant inputs to formulate more effective marketing strategies [33]. The increased consumer awareness of foreign cultures, global markets and foreign brands has increased the importance of studies that explore consumer ethnocentric tendencies [34]. In this context thorough study of consumer ethnocentrism will enable marketers to undergo effective marketing strategies to penetrate the global markets. Organizations need to have the extensive knowledge of the consumer ethnocentricity before internationalize their ventures [35].

\section{Antecedents of Consumer Ethnocentrism}

Although much of the research on the consumer ethnocentric tendencies is carried out in the developed countries, an attempt was made to collect the vast literature review and analyze it for more exploration of the subject. The major antecedents of CET empirically tested by various researchers include socio-psychological, demographic, political and economic categories. The summarizations of variations in research outcomes measuring the correlations between possible antecedents and attitudes towards products of different country of origins are presented in separate tables and integrated graphical framework of the same is presented in Figure 1 (Table 1).

\section{Cultural openness}

Cultural openness is broadly referred as openness of customers to foreign cultures. Shankarmahesh [11] has defined cultural openness as "the opportunity and willingness of people in one culture to interact toward people, values, and artifacts from other cultures". According to Sharma et al. [3] cultural openness is "the willingness of customers to interact with people from other cultures and experience some of their artifacts". Shimp and Sharma [5] stated that cultural openness is negatively correlated with CET, empirically supported by Howard [36] and Ruyter et al. [37] most probably they have heavily relied on the conventional wisdom that travel opportunities and crosscultural interactions leads to more exposures and cultural tolerances, the outcome of which will be to mitigate the consumer ethnocentric tendencies. However, such studies have neglected the maxims of 'familiarity breed contempt' [38] and 'self-reference criteria'(SRC) the meaning of which in cross cultural literature is the tendency to judge other cultures using one's own culture as the reference point [1]. Further, Altintas and Tokol [39] argued that unfavourable attitudes towards foreign brands and xenophobia are closely linked with conservative values and less cultural openness of customers. Thus further insights into the relationships of cultural openness and CET can be provided by taking into account effect of both the potential moderators such as SRC, attitudes towards foreign brands and possible interactions with other antecedents such as xenophobia, animosity and world mindedness.

\section{Conservatism}

Conservatism is the tendency to maintain and preservation of the traditional order of the society that has survived the tests of the time. It is defined as "a tendency to cherish traditions and social institutions that have survived the test of time and to introduce changes only occasionally, reluctantly and gradually" Sharma et al. [3]. They further contended that Conservatism can manifest itself as insistence of strict rules and punishments, religious outlook and an anti-hedonic outlook in its extreme form. The outcome of studies is differing with 
Citation: Tantray S (2018) Consumer Ethnocentrism in 21st Century: A Review and Research Agenda. Bus Eco J 9: 368. doi: 10.4172/21516219.1000368

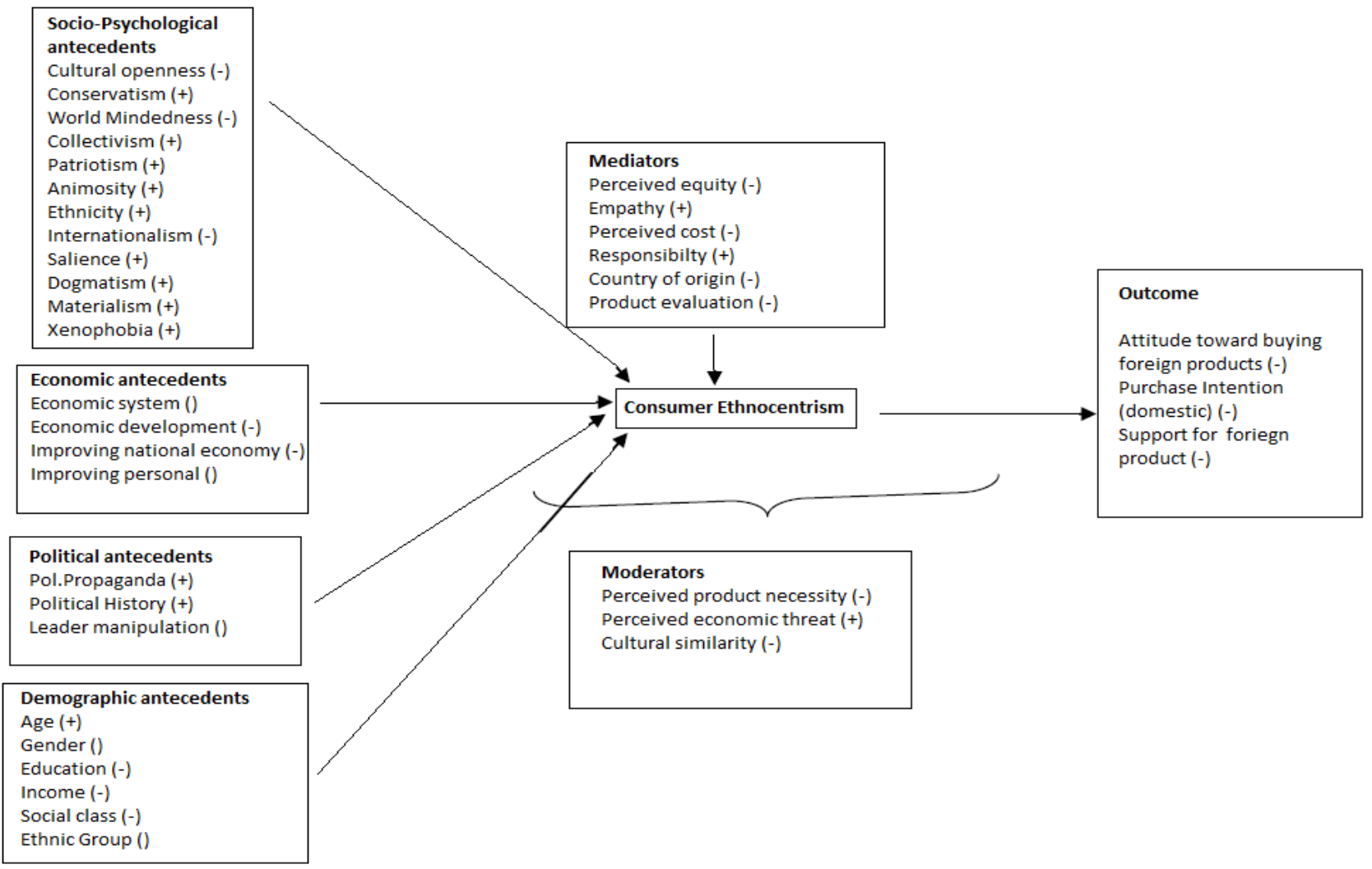

Figure 1: Theoretical framework of antecedents \& Consequences along with mediators \& moderators in relation to CET.

respect to developing and developing countries. Wang [40] contended that the conservatism attribute and favorable attitude towards international brands is having negative relationship in developed countries. However, Sharma et al. [3] and Balabanis et al. [26] noted that conservatism of customers is positively correlated to the CET. Whatever the justifications have been provided for conservatism as a potential antecedent of CET, the criticisms it faces is consumers may conceal their conservative belief while making a purchase decision and also conservatism has become obsolete with the advent of globalization. Thus moderating effects of world mindedness, education and globalization should be given due weightage while studying the impact of conservatism on CET.

\section{World mindedness}

Sometimes used synonymously for internationalism, world minded persons give least importance to nationality or ethnic groups and consider human beings as primary reference groups [41], thereby encouraging people to share common values and maintain empathy towards other societies. Thus, theoretically a person without intercultural interaction aperson can be 'worldminded' [11]. Worldminded consumers are interested in knowledge of international affairs, regards for national harmony and consensus developments [42]. Although negative relationship between the worldmindedness and Consumer ethnocentrism was empirically tested by the Rawwas et al. [41], Bawa [10] and Jain and Jain [12], others such as Balabanis and Adamantios [25] argued that no significant relationship was proved between internationalism (a construct similar to the world mindedness) and the CET. One can certainly argue that world mindedness can be studied as a potential moderator in assessing the relationship between Cultural openness and the CET.

\section{Collectivism}

It is the socio-psychological concept and is defined as the social orientation in terms of personal traits of human beings to peruse collectivist goals rather than individual goals. Hofstede [43] defined it as "collectivistic individuals from birth onwards are integrated into strong, cohesive in-groups, which throughout people's lifetime continue to protect them in exchange for unquestioning loyalty". Collectivism is a major element of individual cultural orientation [44], thus are obligated to favour domestic industries for their economic betterment. Also people scoring high on collectivism tend to reveal more extensive ethnocentric tendencies against individualistic goals [3]. The studies in developed countries $[3,45]$ have shown consistent results of the positive relationship between CET and the Collectivism.

\section{Patriotism}

Various researchers have defined it from different perspectives, such as "sense of national loyalty", "a love of national symbols" [46], devotion to one's own country [3] and commitments of people towards their mother nations [47]. Schatz et al. [48] blind patriotism is "an attachment to country characterized by unquestioning positive evaluation, staunch allegiance, and intolerance of criticism". Schatz et al. [48] contended that patriotism is "an attachment to country characterized by unquestioning positive evaluation, staunch allegiance, and intolerance of criticism". The positive correlation between patriotism and CET supported by various studies such as Han [49], Sharma et al. [3], Klein and Ettenson [50], Balabanis and Adamantios 
Citation: Tantray S (2018) Consumer Ethnocentrism in 21st Century: A Review and Research Agenda. Bus Eco J 9: 368. doi: 10.4172/21516219.1000368

Page 4 of 12

\begin{tabular}{|c|c|c|c|c|}
\hline Antecedent & Researchers & Country & Study type & Relationship to CET \\
\hline \multicolumn{5}{|c|}{ Socio-psychological antecedent } \\
\hline \multirow{4}{*}{ Cultural Openness } & Sharma et al. [3] & Korea & Sample survey & Negative relationship \\
\hline & Suh and Kwon [99] & USA & Sample survey & Negative relationship \\
\hline & Altintas and Tokol [39] & Turkey & Sample survey & Negative relationship \\
\hline & Siemieniako et.al [51] & Poland & Sample survey & Negative relationship \\
\hline \multirow{3}{*}{ Conservatism } & Sharma et al. [3] & Korea & Sample survey & Positive relationship \\
\hline & Suh and Kwon [99] & Austria & Sample survey & Positive relationship \\
\hline & Balabanis et al. [15] & Czech, Turkey & Sample survey & Positive relationship \\
\hline \multirow{2}{*}{ World mindedness } & Rawwas et al. [41] & Austria & Sample survey & Negative relationship \\
\hline & Balabanis et al. [15] & Czech, Turkey & Sample survey & No relationship \\
\hline \multirow{4}{*}{ Collectivism } & Nishina [45] & Japan & Sample survey & Positive relationship \\
\hline & Sharma et al. [3] & Korea & Sample survey & Positive relationship \\
\hline & Hofstede [43] & US & Sample survey & Positive relationship \\
\hline & Siemieniako et.al [51] & Poland & Sample survey & Positive relationship \\
\hline \multirow{5}{*}{ Patriotism } & Han [49] and Klein and Ettenson [50] & US & Sample survey & Positive relationship \\
\hline & Sharma et al. [3] & Korea & Sample survey & Positive relationship \\
\hline & Balabanis et al. [15] & Czech, Turkey & Sample survey & partial support \\
\hline & Siemieniako et al. [51] & Poland & Sample survey & Positive relationship \\
\hline & Evans [103] & Germany & Experiment & Positive relationship \\
\hline \multirow{2}{*}{ Ethnicity } & Siemieniako et al. [51] & Poland & Sample survey & Partial support \\
\hline & Wanninayake and Chovancova [55] & Sri Lanka & Sample survey & Positive relationship \\
\hline \multirow{3}{*}{ Internationalism } & Balabanis et. al., [15] & Czech, Turkey & Sample survey & Negative relationship \\
\hline & Lee et. al., [58] & USA & Field Experiment & Negative relationship \\
\hline & Oh and Zhang [112] & USA & Survey & Negative relationship \\
\hline Salience & Olsen et al. [23] & US & Sample survey & Positive relationship \\
\hline \multirow{2}{*}{ Cultural heritage } & Altintas \& Tokol [39] & Turkey & Sample survey & Positive relationship \\
\hline & Siemieniako et.al [51] & Poland & Sample survey & Positive relationship \\
\hline \multirow{3}{*}{ Dogmatism } & Anderson and Cunningham [19] & US & Sample survey & Positive relationship \\
\hline & Shimp and Sharma [5] & US & Sample survey & Positive relationship \\
\hline & Caruana [61] & Malta & Sample survey & Positive relationship \\
\hline \multirow{3}{*}{ Xenophobia } & Vida et al. [56] & Central European nations & Sample survey & Positive relationship \\
\hline & Siemieniako et.al [51] & Poland & Sample survey & Positive relationship \\
\hline & Altintas and Tokol [39] & Turkey & Sample survey & Strongly Positive \\
\hline $\begin{array}{l}\text { Individual social } \\
\text { responsibility }\end{array}$ & Wanninayake and Dissanayake [55] & Sri Lanka & Sample survey & Positive relationship \\
\hline Materialism & Clarke et al. [66] & Australia, France and Mexico & Sample survey & Positive relationship \\
\hline
\end{tabular}

Table 1: Socio-psychological antecedents of CET and their relationship with CET.

[25] and Siemieniako et al. [51] is not a universal truth. Study conducted by Bannister and Saunders [52] revealed that "the patriotism of British respondents does not extend, with any degree of conviction, into consumer goods markets." Further liberalizations of the trade policies by the federal governments on lines of the WTO can never led to conclusion that such governments are 'unpatriotic' or acting against their nations. Rawwas et al. [41] even argued that an individual can be both patriotic and world minded at the same time. Hence the above discussion calls for the need of exploring the moderating effects of world mindedness and education on the governing relationship between Patriotism and CET.

\section{Ethnicity}

Baumann [53] considered that ethnicity a function of cultural anthropology and Siemieniako et al. (2011) identified it as a sociopsychological antecedent, although some researchers consider it as a demographic antecedent of the CET. Basic tenets of the consumer ethnocentrism holds that consumers overweight the superiority of ingroups rather than out-groups [5]. However, some studies are contrary to it as Klein and Ettenson [50] and Piron [54] did not explore any significant any correlation between ethnicity and CET as against the studies of Wanninayake and Chovancova [55] and Vida et al. [56] who demonstrated the ethnicity as strong predictor of CET.

\section{Internationalism}

There is a slight conceptual difference between internationalism and worldmindedness, the former perceived as positive feelings of people towards foreign countries [57] emphasizing on "international sharing and welfare, and reflects an empathy for the peoples of other countries" and the later (i.e., worldmindedness) encourages people to share common values and maintain empathy towards other societies, however both share the common consequences. The negative correlation between internationalism and consumer ethnocentrism have been empirically stated by authors such as Lee and Back [58] and Zhang et al. [59] in developed countries. However, the positive correlation between buying preference between international brands and the worldmindedness, a construct similar to the internationalism is brought out in the studies of Crawford and Lamb [21] and Rawwas et al. [41]. 


\section{Salience}

Sharma et al. [3] put consumer ethnocentrism as "the beliefs held by consumers about the appropriateness, indeed morality, of purchasing foreign-made products irrespective of the quality or price considerations, purely on nationalist feelings". The moral dimension of ethnocentrism stresses on the fact that losing jobs of workers and putting national economy behind well off nations is solely because of the nationals of a country purchasing products from countries which otherwise are available in domestic countries. Salience signifies the perceived threat to domestic workers Olsen et al. [23] and positive relation of threat perception to ethnocentrism is contended by Rosenblatt [60]. The strong positive correlation between salience and the CET is empirically supported by Olsen et al. [23] but, Shimp and Sharma et al. [5]. included it as moderator rather than antecedent in their conceptual model. There is merit for both the viewpoints as if salience is to be considered as moderating variable or an antecedent of the consumer ethnocentrism.

\section{Dogmatism}

Caruana [61] defined dogmatism as a personality trait to see world in black and white. Anderson and Cunningham [19] found less favorable attitude toward foreign products in more dogmatic consumers to have than their less dogmatic counterparts. The strong positive relationship between dogmatism and consumer ethnocentrism is also exhibited in the studies of Shimp and Sharma [5] and Caruana [61].

\section{Xenophobia}

Xenophobia is defined as the "negative attitude toward, or fear of, individuals or groups of individuals that are in some sense different (real or imagined) from oneself or the group(s) to which one belongs" by Hjerm [62] and is popular socio-psychological concept among researchers. Although xenophobia is created in consumer's minds primarily because of distrust and fear, it enhances their ethnocentric tendencies [63]. The unanimous arguments are that it is the irrational fear of global brands Altintas and Tokol [39]. The authors have found the strong positive empirical support between xenophobia and the consumer ethnocentrism Siemieniako et al. [51].

\section{Materialism}

Rindfleisch et al. [64] observed that lack of satisfying power of inter-personal relationships is filled by materialistic possessions. The dimensions of materialism as pointed by Belk [65] are possessiveness, non-generosity and envy. Rosenblatt [60] contended that consumer ethnocentrism is associated with envy, possessiveness; need to defend one's ego and need to identify with a larger group much like materialism. Clarke et al. [66] has demonstrated a sufficient positive correlation between materialism and consumer ethnocentrism.

\section{Other Socio-Psychological Antecedents of Consumer Ethnocentrism}

Besides the major socio-psychological constructs discussed in holistic literature review on the consumer ethnocentrism, some other antecedents are also introduced by other researchers from various perspectives. Inheritance and individual social responsibility (ISR) are a few to mention Wanninayake and Dissanayake [55]. Altintas and Tokol [39] even argued that negative attitudes towards foreigners can be antecedents of the CET, although it is viewed as consequences of a higher degree of CET by most of the researchers. Furthermore, Consumer affinity is a positive determinant of the consumer ethnocentrism Oberecker and Diamantopoulos [67]. These authors are of the view that even consumer affinity and consumer ethnocentrism are inter-related concepts, there conceptual differences are evident in the manner of defining in-groups and out-groups based on social identity theory.

\section{Economic Antecedents}

Though ethnocentrism is considered as a sociological concept, the holistic term of consumer ethnocentrism has much to do with the economic aspects of nations as a whole. Various researchers have undertaken the studies to analyze the possible relations of economic environment of a nation as possible not only the mediators or moderators but also the major antecedents of the CET. Although results from developing and developed countries show major diversion but are showing relatively consistency when the similar status of individuals from different nations are taken into account. The major economic antecedents pointed out by most of the researchers prevailing in economic system of a country are country's economic system, stages of economic development, economic competitiveness and perceived levels of improving national economy and personal finances (Table 2).

\section{Economic system}

It is the manner which governs the economic activities of a country such as capitalism, socialism or mixed economy. The ethnocentric and nationalists feelings of people of a country are directly influenced by prevailing economic system of a country [68]

\begin{tabular}{|c|c|c|c|c|}
\hline Antecedent & Researchers & Country & Study type & Relationship to CET \\
\hline \multicolumn{5}{|c|}{ Economic antecedents } \\
\hline \multirow{3}{*}{ Economic System } & Rosenblatt [60] & $\mathrm{N} / \mathrm{A}$ & theoretical & Negative relationship \\
\hline & Weiss [68] & $\begin{array}{l}\text { Slovakia, Czech, } \\
\text { Hungary and Poland }\end{array}$ & Sample Survey & Negative relationship \\
\hline & Aruskeviciene et. al. [70] & 13 European countries & $\begin{array}{c}\text { Field } \\
\text { Experiment }\end{array}$ & Weak relationship \\
\hline \multirow{3}{*}{$\begin{array}{l}\text { Stage of economic } \\
\text { development }\end{array}$} & Good and Huddleston [72] & Russia, Poland & Experiment & $\begin{array}{l}\text { Negative relationship in initial phase of transitional economies and developed } \\
\text { economies \& a positive relationship for Intermediate stage of transition. }\end{array}$ \\
\hline & Durvasula et al. [27] & Russia & Sample survey & Negative relationship \\
\hline & Reardon et. al [73] & $\begin{array}{l}\text { USA, Slovenia and } \\
\text { Kazakhstan }\end{array}$ & Survey & Negative relationship for transitional economies. \\
\hline $\begin{array}{l}\text { Improving national } \\
\text { economy }\end{array}$ & Klein and Ettenson [50] & United States & Sample survey & Negative relationship \\
\hline $\begin{array}{l}\text { Improving personal } \\
\text { finances }\end{array}$ & Klein and Ettenson [50] & United States & Sample survey & Negative relationship \\
\hline
\end{tabular}

Table 2: Economic antecedents of CET and their relationship with CET. 
Capitalism which encourages people to hold ownership properties is negatively associated with the CET [60], which is further empirically substantiated by Weiss [68] from the research on citizens from four post-communist countries: Czech Republic, Slovakia, Hungary and Poland, while as socialistic economies are more conservative and are expected to have more ethnocentric tendencies [69]. Aruskeviciene et al. [70] noted a unique model of CE from a study on 13 transitional economies in Europe and authors are of the opinion that consumers prefer to buy domestic products as there is a weak relationship between cosmopolitism and CET in those transitional economies. However, there is practically a dearth of literature highlighting the relationship of economic antecedents and CET in developing economies.

\section{Economic development}

Stages of development of a country are a major influencing factor on consumer's ethnocentric tendencies. A comprehensive framework linking different stages of economic development to consumer's preferences for domestic and foreign goods is sketched by Schuh [71]. As per the framework, the early stages of the transition (from state control to market control) are marked by the preference for foreign products because of high quality, status and curiosity motives. However, in the intermediate mode of transition, dominancy of nationalist motives are observed and further reversed upon attaining the developed status. The said framework is also supported by Good and Huddleston [72] in the contexts of Poland and Russia [27]. Klein and Ettenson [50] are of the view that consumers go for the expensive imported goods with the rise in their disposable incomes and thus confirming the negative relationship between economic development and the CET, also justified by the comparative studies of the USA, Slovenia and Kazakhstan by Reardon et al. [73], confirming the stronger association of consumer ethnocentric tendencies in the contexts of less developed transitional economies.

\section{Personal finances and belief of improving the national economy}

In developed countries, like US the negative relationship between beliefs of improving national economy and the consumer ethnocentrism was observed by Klein and Ettenson [50]. Authors also argued that reduced levels of CET are the result of improved personal financial situation. The positive correlation between individual income levels of consumers and the preferences for the foreign brands primarily because of the status related consumer purchasing behaviour was explored by Supphellen and Gronhaug [74]. Klein and Ettenson [50] further contended that in developed countries less degree of ethnocentrism is observed when people believe that their national economies have been improved within the last couple of years. Contrary to that, Wang and Chen [30] noted that in developed countries consumers prefer domestic brands as they perceive them to be of high quality and people from developing countries are highly satisfied with preferring products from developed countries.

\section{Political Antecedents}

\section{Political environment}

In addition to the economic antecedents to CET, Shankarmahesh [11] has categorized some political antecedents to CET which emerge from the political environment of a country and which include Political propaganda, History of oppression, Leader manipulation etc. mentioned in Table 3.

\section{Political propaganda}

Political propaganda is informal mentoring of the governments to their nationals for the purpose of changing their attitudes regarding local brands. These campaigns are also promoted by some non-profit organizations in some countries. Political propaganda was posited as an antecedent of the CET by Rosenblatt way back in 1964. The author contended that by raising the bogey of threat by out-groups, the leaders can increase the group ethnocentrism to a greater extent and the magnitude of which is an empirical question to answer. It is worth mentioning to study the role of 'political orientation' as a moderator governing the relationship between political propaganda and the CET, while as Shankarmahesh [11] argued that impact of political propaganda can be moderated by political freedom of the country. The 'buy local' campaigns promoted by the most of the governments shows varying acceptability in the diasporas of the countries [75]. Elliot [76] further claimed that "buy local" campaigns show sufficient influence ethnocentric groups in less developed countries like Indonesia. The impact of 'made in India' campaign in the political philosophy of the country on the consumer ethnocentrism in Indian consumers is a worth question to be ascertained.

\section{Political history}

Besides political propaganda, political histories of countries considerably determine the level of CET among their nationals. Rosenblatt [60] argued that countries with a long history of oppressions, a strong emotional feeling to reject out-group values are increased besides enhancing in-group cohesiveness, which is in line with the studies of Good and Huddleston [72] who posited that CET of Polish customers is higher as an oppressed nation than Russian customers. However, it can be argued that as compared to the products of the conquered nation's consumers of conquering nations will tend to view the 'in-group' products as more superior and preferable. Shankarmahesh [11] emphasized the need for more investigation on the combined effect of political propaganda and the political history of the countries on the ethnocentrism. Since India was for a long time under the rule of the west, the consumers are expected to show the moderated behaviour while making the purchasing intentions.

\section{Leader manipulation}

In addition to the studies of Rosenblatt mentioned above, the

\begin{tabular}{|c|c|c|c|c|}
\hline Antecedent & Researchers & Country & Study type & Relationship to CET \\
\hline \multicolumn{5}{|c|}{ Political antecedents } \\
\hline Political propaganda & Rosenblatt [60] & N/A & $\mathrm{N} / \mathrm{A}$ & Positive relationship \\
\hline \multirow{2}{*}{ Sovereignty } & Yu and Albaum [102] & Hong Kong & Sample Survey & Positive relationship \\
\hline & Lao [77] & Canada & Sample Survey & Positive relationship \\
\hline History of oppression & Good and Huddleston [72] & Poland & Experiment & Positive relationship \\
\hline Proximity, size and power of out-groups & Rosenblatt [60] & N/A & N/A & Positive relationship \\
\hline Leader manipulation & Rosenblatt [60] & N/A & N/A & Positive relationship \\
\hline
\end{tabular}

Table 3: Political antecedents of CET and their relationship with CET. 
author further contended that leader possesses the power to manipulate the ethnocentric beliefs of a group. Therefore, when leaders conduct programmes to encourage the homogeneity and mutual familiarity of the in-group members, it is a clear motivation to intensify ethnocentric feelings among the customers of the nation. However, Wanninayake and Chovancova [55] argued that this factor commands less validity in modern political environment because of the fact that people are more concerned about the good governance practices rather than showy campaigns.

\section{Sovereignty}

The concept of sovereignty was introduced by Jean Bodin in 16th century with emphasis on fact that freedom of the nation from outside influences is the basic right of any country. Most of the political theories are in consensus with the observation that sovereignty is a situation where supremacy of authority is decided by the territorial legislature elected by the general population of that country. Lao [77] explored that sovereignty of a country has a direct impact on the commitment of people towards their motherland. The author further argued that in Canadian context sovereignty is positively associated with both ethnocentrism and colonialism.

\section{Demographic Co-variates and Cethnocentrism}

The demographic antecedents of the CET are comprehensively reported by most of the researchers in addition to import purchasing behaviour. The sole advantage of which is the demographic segmentation of consumers based on their favorable disposition to foreign products. Most of the previous researchers [11,78] etc.) are of the basic view that understanding the relationship between demographic variables and the consumer ethnocentrism is utmost for marketers in determining the sensitivity of domestic buyers to foreign brands. However, Wanninayake and Chovancova [55] are of the view that intensity of CET can vary according to demographic variables although they may not generate consumer ethnocentrism in human minds. The summation of previous research pertaining to demographic antecedents to the CET is mentioned in Table 4.

\section{Age}

More cosmopolitanism of younger generation due to socio-cultural influences in the recent past their tendency to be less ethnocentric is argued by Shankarmahesh [11] and it is further justified by research findings of Javalgi and Scherer [79] and Chryssochoidis et al. [80] demonstrating a low score in the CET scale for young customer groups in compared for conservative elders. Although there is mixed empirical evidence for the arguments that younger people are less ethnocentric Klein and Ettenson [50], some studies did not find any significant relationship between the two [3], while Schooler [81] and Bannister

\begin{tabular}{|c|c|c|c|c|}
\hline Antecedent & Researchers & Country & Study type & Relationship to CET \\
\hline \multicolumn{5}{|c|}{ Demographic antecedents } \\
\hline \multirow{5}{*}{ Age } & Good and Huddleston [72] & Poland & Field Experiment & Positive relationship \\
\hline & Sharma et al. [3] & Korea & Sample survey & No relationship \\
\hline & Bawa [10] & India & Field Experiment & Younger generation less ethnocentric \\
\hline & Javalgi et al. [79] & France & Field Experiment & Younger less ethnocentric \\
\hline & Chryssochoidis et al. [80] & Greece & Field Experiment & Ethnocentrism increases with age. \\
\hline \multirow{7}{*}{ Gender } & Bannister and Saunders [52] & Britain & Interviews & Men more ethnocentric \\
\hline & Wall and Heslop [116] & Canada & Sample survey & Females more ethnocentric \\
\hline & Han [49] & US & Sample survey & Females more ethnocentric \\
\hline & Sharma et al. [3] & Korea & Sample survey & Women more ethnocentric \\
\hline & Good and Huddleston [72] & Russia & Experiment & No relationship \\
\hline & Balabanis et al. [15] & Turkey & Sample survey & Women more ethnocentric \\
\hline & Saffu and Walker [114] & Canada and Russia & Field Experiment & Females more ethnocentric \\
\hline \multirow{5}{*}{ Income } & Sharma et al. [3] & Korea & Sample survey & Negative relationship \\
\hline & Balabanis et al. [15] & Turkey & Sample survey & Negative relationship \\
\hline & Balabanis et al. [15] & Czech & Sample survey & Positive relationship \\
\hline & Lee et al. [58] & USA & Field Experiment & Positive relationship \\
\hline & Javalgi et al. [79] & France & Field Experiment & Positive relationship \\
\hline \multirow{7}{*}{ Education } & Han [49] & US & Sample survey & No relationship \\
\hline & Nishina [45] & Japan & Sample survey & Negative relationship \\
\hline & Caruana [61] & Malta & Sample survey & Negative relationship \\
\hline & Balabanis et al. [15] & Turkey & Sample survey & Negative relationship \\
\hline & Balabanis et al. [15] & Czech & Sample survey & No relationship \\
\hline & Saffu and Walker [114] & Canada \& Russia & Sample survey & Negative relationship \\
\hline & Chryssochoidis et al. [80] & Greece & Sample survey & Limited relationship \\
\hline \multirow{3}{*}{ Social class } & Han [49] & United States & Sample survey & Blue-collar more ethnocentric than white-collar \\
\hline & Klein and Ettenson [50] & United States & Sample survey & Middle-class less ethnocentric than working class. \\
\hline & Klein and Ettenson [50] & USA & Sample survey & Non-members less ethnocentric than union members. \\
\hline \multirow{4}{*}{$\begin{array}{l}\text { Race/ethnic } \\
\text { group }\end{array}$} & Klein and Ettenson [50] & USA & Sample survey & No relationship \\
\hline & Piron [54] & Singapore & Sample survey & No relationship among ethnic groups \\
\hline & Zarkada-Fraser and Fraser [91] & Australia & Sample survey & Minorities with a unique cultural group are less ethnocentric \\
\hline & Al Ganideh and Al Taee [95] & Jordon & Field Experiment & No significant relationship \\
\hline
\end{tabular}

Table 4: Demographic antecedents of CET and their relationship with CET. 
and Saunders [52] find positive relationship between age and favorable foreign product evaluation.

\section{Gender}

In analyzing the behavioural aspects of the customers gender is of prominent importance [82] and with respect to the relationship of gender and CET there is no consensus among various researchers [79]. Most of the studies reveal that women are more ethnocentric than the men $[3,83,15,79]$ evaluating unfavorably the foreign products possibly because of more conservativist and conformist nature [49] or having higher tendencies for maintaining social harmony [84]. However, some studies did not find any sufficient gender difference with respect to CET [61], while as other studies found females to be less ethnocentric than men [52].

\section{Education}

Education is generally pretended to be a tool for making people's mind broad [85] and a very helpful means to diminish conservative tendencies [86]. Most of the researchers have proved empirically that educational levels of the customers is negatively related to the CET $[58,87,80]$ mainly more educated persons are less likely to have ethnic prejudices, while some contrary studies by Han [49] who did not find any significant relationship between educational levels of consumers and ethnocentrism.

\section{Income}

Income is considered an important factor influencing the customer decision making [88]. A majority of studies have concluded that income is a demographic antecedent of consumer ethnocentrism but the findings show fluctuations. Sharma et al. [3]; Bruning [83]; Balabanis et al. [15] Lee and Back [58] etc. have demonstrated a negative correlation between consumer's income levels and CET. The authors are of the view that increased income levels provide the opportunity for travel and gain cross border experience, eventually inculcating them to hold cosmopolitan views. The results are contrary in some studies [49] and even reversal i.e., positive relation between income and CET is reported by Tan and Farley [89].

\section{Social class}

Kotler [88] observed that "social classes are relatively homogeneous and enduring divisions in the society", thus sharing a common pattern in consumer buying decisions [82]. According to Shankarmahesh [11], the magnitude of the correlation between income and CET can be extended proportionately with the social class and CET i.e., one can hypothesize that as consumers move up the social ladder, their ethnocentric tendencies tend to fall. This hypothesis is also supported by Han [49] and Klein and Ettenson [50]. However, no consistent pattern is observed regarding the negative correlation of social class and CET, which is evident from the studies of Sharma et al., [3] who demonstrated that consumers from the upper class are more ethnocentric than upper middle and lower classes. Even Caruana [61] argued that occupation, a main determinant in social class is not related to CET, thus concluding that social class and CET are remotely correlated.

\section{Ethnic group/race}

There is a diverse opinion from minority and non-minority communities for the preference to domestic/foreign countries. The research questions regarding the inter-ethnic group differences in consumer ethnocentrism have yielded different results. Studies of Cottingham and Morris [90] and Zarkada-Fraser and Fraser [91] have concluded that minorities to be more favorable to foreign brands than majority ethnic groups while as Klein and Ettenson et al., [92] and Piron [54] finds race non-significant for CET (Table 5).

\section{Consequences of Consumer Ethnocentrism}

Primary consequence of interest is that whether ethnocentrism really matters for the consumers of a nation which has been researched extensively by Sharma et al. [3] and Orth and Firbasova [93]. From previous researches, several operational definitions for possible consequences of CET can be inferred. Researchers have used different constructs such as 'attitude toward buying foreign products' [94]; 'purchase intention' [80] 'Support for foreign products' [12] 'willingness to buy domestic products' [51] and 'willingness to buy foreign products' [12]. However, Al Ganideh and Al Taee [95] maintained that sources of consumer ethnocentrism have not been well acknowledged. What leads consumers to score high on the scale of consumer ethnocentrism is an important research questions to be determined. Furthermore, argued that international marketers considerably influence the ethnocentric tendencies of foreign customers along with preservation of the wellbeing of other stake holders popularly known as international quality of life orientation (IQOL). John and Brady [96] categorized the consequences of consumer ethnocentrism from previous researches in three groups. First refers to "beliefs of consumers about the prestige of local and foreign brands, characteristics and quality of local and foreign-made products and buying imported products", second consists of "general attitudes toward foreign products, advertising and brands" and third is associated with "consumers' purchasing intentions". The relationship between CET and outcome variables along with the influence of mediator and moderator variables are discussed and summarized in the table below.

\section{Direct Consequences}

Conceptually there is by and large unanimous position on the argument that consumer ethnocentrism is positively correlated to favorable evaluation of domestic products and with few exceptions in a few cases, all of the previous studies provide empirical evidence for justifying the above argument [97]. The positive relationship between CET and purchase intention of domestic products is empirically supported by studies of Herche [22], Kim and Pysarchik [98], and Chryssochoidis et al. [80]. However, a strong negative relation between CET and willingness to buy foreign products is empirically demonstrated in studies of Klein et al. [9] Suh and Kwon [99] (Figure 1).

\section{Consequences through Mediators}

Numerous mediators were proposed by various researchers and the consequences of their effects on consumer ethnocentrism. Oslen et al. [23] conducted their study in US and offered empathy, perceived equity, costs and responsibility as possible mediators between CET and willingness to go for imported products. Consumer ethnocentrism is considered of having positive influence on empathetic feelings for other persons considered similar to the consumer, which has congruence with the Rosenblatt's [60] hypothesis increase in in-group solidarity is a function of increased empathy which will increase the tendency to buy domestic products among the in-groups. CET was posited to negatively influence the perceived equity mainly because of the fact that ethnocentric consumers feel that international competition is devastating for the domestic industries which subsequently will induce consumers to go for domestic commodities. Decrease in perceived costs was also suggested by Olsen et al. [23] for helping the in-groups. To put it in other way, for buying domestic products ethnocentric consumers 
Citation: Tantray S (2018) Consumer Ethnocentrism in 21st Century: A Review and Research Agenda. Bus Eco J 9: 368. doi: 10.4172/21516219.1000368

Page 9 of 12

\begin{tabular}{|c|c|c|c|c|}
\hline Direct & Researcher & Country & Study Type & Relation to CET \\
\hline \multirow{4}{*}{$\begin{array}{l}\text { Attitude toward buying } \\
\text { foreign products }\end{array}$} & Zarkada-Fraser and Fraser [91] & Australia & Sample survey & Negative relationship \\
\hline & Klein et al., [108] & China & Sample survey & Negative relationship \\
\hline & Saffu nad Walker [114] & Canada \& Russia & Sample survey & Not significant \\
\hline & Kwak et al., [94]; Jain et al., [12] & US, Korea \& India & Sample survey & Negative relationship \\
\hline \multirow{4}{*}{$\begin{array}{l}\text { Purchase intention to } \\
\text { buy domestic products }\end{array}$} & Bruning [83] & Canada & $\begin{array}{l}\text { Experiment and sample } \\
\text { survey }\end{array}$ & Price more important that CET \\
\hline & Klein et al. [108] & China & Mall intercepts & Positive relationship \\
\hline & Chryssochoidis et al., [80] & Greece & Sample survey & No significance \\
\hline & Suh and Kwon [99] & USA & Sample survey & Positive relationship \\
\hline \multirow{4}{*}{$\begin{array}{l}\text { Support for foreign } \\
\text { products }\end{array}$} & Zarkada-Fraser and Fraser [91] & Australia & Sample survey & Negative relationship between CET and support for foreign store \\
\hline & Klein et al., [108] & China & Sample survey & Negative relationship \\
\hline & Chryssochoidis et al., [80] & Greece & Sample survey & Price more significant \\
\hline & Jain et al., [12] & India & Sample survey & Negative relationship \\
\hline \multicolumn{5}{|c|}{ Role of Mediators } \\
\hline Perceived equity & Olsen et al. [23] & USA & Sample survey & Negative relationship \\
\hline Empathy & Olsen et al. [23] & USA & Sample survey & Positive relationship \\
\hline Perceived costs & Olsen et al. [23] & USA & Sample survey & Negative relationship \\
\hline Responsibility & Olsen et al. [23] & USA & Sample survey & Positive relationship \\
\hline \multirow[t]{2}{*}{ Country of origin } & Han [49]; & USA & Sample survey & Positive (moderated by product importance) \\
\hline & Wang and Chen [30] & China & & \\
\hline \multirow{4}{*}{ Product evaluation } & Klein et al. [108] & China & Mall intercepts & Negative relationship \\
\hline & Moon and Jain [111] & USA & Sample survey & Negative relationship \\
\hline & Huddleston et al. [78] & Poland & Experiment & Negative relationship \\
\hline & Yu and Albaum [102] & Hong Kong & Sample survey & $\begin{array}{c}\text { Negative (CET related to purchase behavior through product } \\
\text { preferences) }\end{array}$ \\
\hline \multicolumn{5}{|c|}{ Role of Moderators } \\
\hline $\begin{array}{l}\text { Perceived product } \\
\text { necessity }\end{array}$ & Sharma et al. [3] & Korea & Sample survey & $\begin{array}{l}\text { Ethnocentrism influences negative attitudes more toward } \\
\text { "unnecessary" foreign products }\end{array}$ \\
\hline $\begin{array}{l}\text { Perceived economic } \\
\text { threat }\end{array}$ & Sharma et al. [3] & Korea & Sample survey & $\begin{array}{l}\text { Negative attitude (more for products perceived as threats to } \\
\text { home economy). }\end{array}$ \\
\hline Cultural similarity & Watson and Wright [16] & New Zealand & Sample survey & High cultural similarity leads to favorable product evaluations. \\
\hline
\end{tabular}

Table 5: Consequences of CET, mediators and moderators and their possible relationship.

tend to disregard the personal economic costs, thereby proving the price inelastic nature of the CET. The authors also argued that with decrease in perceived equity, consumers tend to be more responsible and hence leading to go for domestically manufactured products instead foreign products. Besides the above mentioned mediating variables of Olsen et al [23], Han [49] and Brodowsky [100] suggested 'Country of Origin (COO)' effect as another mediating variable between consumer patriotism and purchase intention. The authors concluded that in developed countries patriotism affected country image but the importance of the product moderated their relationship. Samiee [101] and Brodowsky [100] undertook the comprehensive literature review of 'Country of Origin effects (COO)' and included consumer ethnocentrism as one of the major antecedents along with product class attributes and country's level of economic development. However, there is considerable inconsistency in the empirical results regarding the relationship between image of a country and purchase intention. Thus, CET being an affective and normative construct may lead to country of Origin effect which is basically a cognitive construct. Lastly, 'Product evaluation' is also included among the mediating variables by Shimp and Sharma [5] empirically supported by the Klein et al. [9] and $\mathrm{Yu}$ and Albaum [102] with respect to foreign product evaluation. However, no significant relationship between CET and foreign product quality evaluation was studied in US by Kim and Pysarchik [98] and for certain Japanese products even positive relationship was ascertained [102-106]

\section{Consequences through Moderators}

Two moderating variables i.e., 'perceived product necessity' and 'perceived economic threat' were suggested by Sharma et al. [3] between consumer ethnocentrism and consumer attitudes foreign products. The former is the extent to which consumers believe that an outsider product is indispensable due to its absolute necessity. The authors concluded that CET influenced negative attitudes more towards foreign products perceived 'unnecessary'. Perceived economic threat is a concept similar to 'salience' earlier discussed under the sociopsychological construct. The authors contended that CET influenced attitudes mainly for those products that are perceived as threat to the home economy as a whole. Another moderating variable 'Cultural similarity' was introduced by Watson and Wright [16] upon a study on consumers in New Zealand and concluded that consumers with high CET use cultural similarity of source country for product attitudes and product evaluations [107-116].

\section{Results and Conclusion}

The aim of the present study is to provide a comprehensive review of the antecedents and consequences of CET along with possible effects of mediating and moderating variables in addition to presentation of an integrated framework and detailed summary tables. For full exploration of the subject each possible antecedent and consequence is individually discussed and suggestions for future research were also 
provided. From integrative review and frame work broad research directions can also be drawn. Like as, thorough analysis of consumer ethnocentrism in the service sector need to be studied as most of the economies of the world are service economies and CET has not been fully explored in services. Also the impact of globalization and the consumer attitudes for hi-tech products, belief of nationals in foreign collaborations in various projects from agriculture to national security demands a comprehensive investigation and explanation for relevance of CET in such circumstances. The success of 'buy local' campaigns by governments in institutionalizing the consumer ethnocentrism on one hand and integrating the FDI in the country's economies to overcome ethnocentrism on other hand are noteworthy research questions. Although marketing managers of small domestic countries can take the advantage of prevalent ethnocentric tendencies by promoting the 'native' image so that international competitors can be held at bay but multi-nationals can face serious problems in repeating the same, thereby demanding more research in exploring the effectiveness of these strategies. Given the heterogeneity of the populations both between and within transitioning economies, the future researchers need to examine these issues at the intra-country level. Information generated from such studies can provide a basis for a better understanding of microenvironment of countries at various levels of economic development as well as their consumer markets. This paper will not only enrich the vast body of knowledge in consumer behaviour and marketing in the transitional markets but will also provide the broad avenues for further research in the marketing field.

\section{References}

1. Jeannet JP, Hennesy HD (1995) Global Marketing Strategies, (3rd edn.), Houghton.

2. Porter MEPME (1986) Competition in Global Industries, Harvard Business School Press, Boston, MA.

3. Sharma S, Shimp TA, Shin J (1995) Consumer Ethnocentrism: A Test of Antecedents and Moderators. J Acad Market Sci 23: 26-37.

4. Kotabe M, Helsen K (1998) Global Marketing Management, Wiley, New York, NY.

5. Shimp TA, Sharma S (1987) Consumer ethnocentrism: construction and validation of the CETSCALE. J Market Assoc 24: 280-289.

6. Sumner WG (1906) Folkways: The Sociological Importance of Usages, Manners, Customs, Mores, and Morals. Ginn \& Co., New York, NY.

7. Murdock GP (1931) Ethnocentrism. In: Seligman ERA editor. Encyclopaedia of the Social Sciences, Macmillan, New York, NY, pp: 613-614.

8. Barger K (2003) Ethnocentrism: What Is It? Why Are People Ethnocentric? What Is the Problem? What Can We Do about It?

9. Klein JG, Ettenson R, Morris M (1998) The animosity model of foreign product purchase: an empirical test in the People's Republic of China. J Market 62 89-100.

10. Bawa A (2004) Consumer Ethnocentrism: CETSCALE Validation and Measurement of Extent. Vikalpa 29: 43-57.

11. Shankarmahesh MN (2006) Consumer Ethnocentrism: An Integrated Review of Its Antecedents and Consequences. Int Market Rev 23: 146.

12. Jain SK, Jain R (2010) Consumer Ethnocentrism, Its Antecedents and Consequences to Consumer Attitudes towards Domestic and Foreign Made Products: A Theoretical Framework. Bus Analyst 31: 23-46.

13. Lynn R (1976) The sociobiology of nationalism. New Society, pp: 11-14.

14. Dreu CKW, Shalvi S, Smidts A, Sanfey AG (2012) The Herding Hormone Oxytocin Stimulates In-Group Conformity. J Assoc Psychol Sci 23: 1288-1292.

15. Balabanis G, Diamantopoulos A, Mueller RD, Melewar TC (2001) The impact of nationalism, patriotism and internationalism on consumer ethnocentric tendencies. J Int Bus Stud 32: 157-175.

16. Watson JJ, Wright $\mathrm{K}(2000)$ Consumer Ethnocentrism and Attitude toward Domestic and Foreign Products. Eur J Market 34: 1149-1166.
17. Upadhyay Y, Singh SK (2006) Preference for Domestic Goods: A Study of Consumer Ethnocentrism. J Bus Perspect 10: 59-68.

18. Kumar A, Fairhurst A, Kim Y (2011) Ethnocentric tendencies of Indian consumers: impact on preference for domestic versus foreign products. Int Rev Retail, Distrib Consum Res 21: 323-341.

19. Anderson WT, Cunningham WH (1972) Gauging foreign product promotion. J Advertising Res, pp: 29-34.

20. Dornoff RJ, Tankersley CB, White GP (1974) Consumers' perceptions of imports. Akron Bus Econ Rev, pp: 26-29.

21. Crawford JC, Lamb CW (1981) Source preferences for imported products. $J$ Purchasing Mater Manage, pp: 28-33.

22. Herche J (1992) A note on the predictive validity of the CETSCALE. J Acad Market Sci 20: 261-264.

23. Olsen JE, Granzin KL, Biswas A (1993) Influencing consumers' selection of domestic versus imported products: implications for marketing based on a model of helping behaviour. J Acad Market Sci 21: 307-321.

24. Netemeyer RG, Durvasula S, Lichenstein DR (1991) A Cross-national Assessment of the Reliability and Validity of the CETSCALE. J Market Res 28: 320-327.

25. Balabanis G, Adamantios D (2004) Domestic Country Bias, Country-ofOrigin Effects, and Consumer Ethnocentrism: A Multidimensional Unfolding Approach. J Acad Market Sci 32: 80-95.

26. Balabanis G, Mueller R, Melewar TC (2002) The relationship between consumer ethnocentrism and human values. J Global Market 15: 7.

27. Durvasula S, Andrews CJ, Netemeyer RG (1997) A cross-cultural comparison of consumer ethnocentrism in the United States and Russia. J Int Consum Market 9: 73-93.

28. Hult GTM, Keillor BD, Lafferty BA (1999) A Cross-national Assessment of Social Desirability Bias and Consumer Ethnocentrism. J Global Market 12 29-43.

29. Luque-Martinez T, Ibanez-Zapata JA, Barrio-Garcia S (2000) Consumer ethnocentrism measurement - an assessment of reliability and validity of the CETSCALE in Spain. Eur J Market 34: 1353.

30. Wang LC, Chen XZ (2010) Consumer ethnocentrism and willingness to buy domestic products in a developing country setting: testing moderating effects. J Consum Market 21: 391-400.

31. Chung JE (2011) Consumer purchase intention for organic personal care products. J Consum Market 28: 40-47.

32. Josiassen A (2011) Consumer Dis-identification and Its Effects on Domestic Product Purchases: An Empirical Investigation in the Netherlands. J Market 75: 124-140.

33. Chéron E, Hayashi H (2001) The Effect of Respondents' Nationality and Familiarity with a Product Category on The Importance of Product Attributes in Consumer Choice: Globalization and the Evaluation of Domestic and Foreign Products. Jpn Psychol Res 43: 183-194.

34. Nijssen EJ, Douglas SP (2008) Consumer world-mindedness, socialmindedness, and store image. J Int Market 16: 84-107.

35. Phau I, Chan KW (2003) Targeting East Asian markets: a comparative study on national identity. J Target, Meas Anal Market 12: 157-172.

36. Howard DG (1989) Understanding how American consumers formulate their attitudes about foreign products. J Int Consum Market 2: 7-24.

37. Ruyter KD, Birgelen MV, Wetzels M (1998) Consumer ethnocentrism in international services marketing. Int Bus Rev 7: 185-202.

38. Wirth $L$ (1936) Types of nationalism. Am J Soc 41: 723-737.

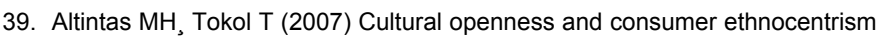
an empirical analysis of Turkish consumers. Market Intell Plann 25: 308-325.

40. Wang CK (1978) The Effect of Foreign Economic, Political, and Cultura Environments on Consumers' Willingness to Buy Foreign Products. A\&M Texas University.

41. Rawwas MYA, Rajendran KN, Wuehrer GA (1996) The Influence of Worldmindedness and Nationalism on Consumer Evaluation of Domestic and Foreign Products. Int Market Rev 13: 20-38.

42. Gomberg P (1994) Universalism and optimism. Ethics 104: 536-557. 
43. Hofstede G (2001) Culture's Consequences: International Differences in Work Related Values, Sage, Beverly Hills, CA.

44. Yoo B, Donthu N (2005) The Effect of Personal Cultural Orientation on Consumer Ethnocentrism: Evaluations and Behaviors of U.S. Consumers Toward Japanese Products. J Int Consum Market 18: 07-44.

45. Nishina S (1990) Japanese consumers: introducing foreign products/brands into the Japanese market. J Advertising Res, pp: 35-45.

46. Theiss-Morse E (2003) National Identity and Self-Esteem. Perspect Polit 1 515-532.

47. Huddy L, Khatib N (2007) American patriotism, national identity, and political involvement. Am J Polit Sci 51: 63-77.

48. Schatz R, Staub E, Lavine H (1999) On the Varieties of National Attachment: Blind versus Constructive Patriotism. Polit Psychol 20: 151-174.

49. Han CM (1988) The role of consumer patriotism in the choice of domestic versus foreign products. J Advertising Res, pp: 25-32.

50. Klein JG, Ettenson R (1999) Consumer animosity and consumer ethnocentrism: an analysis of unique antecedents. J Int Consum Market 11: 5.

51. Siemieniako D, Kubacki K, Glinska E, Krot K (2011) National and regional ethnocentrism: a case study of beer consumers in Poland. Brit Food J 113 404-418.

52. Bannister JP, Saunders JA (1978) UK consumers' attitudes towards imports: the measurement of national stereotype image. Eur J Market 12: 562-570.

53. Baumann Z (2004) Identity Cambridge: Polity Press. In: Callender CO, Miles PV editors. Obstacles to organ donation in ethnic minorities. Paediatr Transpl 5: 383-385.

54. Piron F (2002) International out shopping and ethnocentrism. Eur J Market 36: 189-210.

55. Wanninayake WMCB, Chovancova M (2012) Consumer Ethnocentrism and Attitudes towards Foreign Beer Brands: With Evidence from Zlin Region in the Czech Republic. J Competitiveness 4: 3-19.

56. Vida I, Dmitrovic T, Obadia C (2008) The role of ethnic affiliation in consume ethnocentrism. Eur J Market 42: 327-343.

57. Kosterman R, Feshbach S (1989) Toward a measure of patriotic and nationalistic attitudes. Polit Psychol 10: 257-274.

58. Lee JS, Back KJ (2008) Attendee-based brand equity. Tourism Manage 29: 331-344.

59. Zhang $\mathrm{Y}$, Lin MC, Nonaka A, Beom K (2005) Harmony, hierarchy and conservatism: a cross-cultural comparison of confucian values in China, Korea, Japan, and Taiwan. Commun Res Rep 22: 107-115.

60. Rosenblatt PC (1964) Origins and effects of group ethnocentrism and nationalism. J Conflict Resolut 8: 131-146.

61. Caruana A (1996) The effects of dogmatism and social class variables on consumer ethnocentrism in Malta. Market Intel Plann 14: 39.

62. Hjerm M (1998) National identities, national pride, and xenophobia: A comparison of four Western countries. Acta Sociologica 41: 335-347.

63. Mcevoy CJ (2002) A consideration of human xenophobia and ethnocentrism from a socio-biological perspective. Hum Rights Rev 3: 39-49.

64. Rindfleisch A, Burroughs JE, Denton F (1997) Family structure, materialism, and compulsive consumption. J Consum Res 23: 312-325.

65. Belk RW (1984) Three scales to measure constructs related to materialism: reliability, validity, and relationships to measures of happiness. Assoc Consum Res, pp: 291-297.

66. Clarke I, Shankarmahesh MN, Ford JB (2000) Consumer ethnocentrism, materialism and values: a four country study. AMA Winter Educators' Conference Proceedings, San Antonio, TX.

67. Oberecker EM, Diamantopoulos A (2011) Consumers' emotional bonds with foreign countries: Does consumer affinity affect behavioral intentions? J Int Market 19: 45-72.

68. Weiss JW (2003) Business Ethics: A Stakeholder and Issues Management Approach. South-Western, Thomson Learning.

69. Wilson GD (1973) A dynamic theory of conservatism, London: Academic
Press.

70. Aruskeviciene V, Satova J, Reardon J (2012) Success factors of e-commerce in transitional economies. International Handbook of Academic Research and Teaching, In Proceedings of Intellect base International Consortium 25: 37-19.

71. Schuh A (1994) Marketing in East Central Europe: an evolutionary framework for marketing strategy development. paper presented at Conference on Marketing Strategies for Central and Eastern Europe, Vienna.

72. Good LK, Huddleston P (1995) Ethnocentrism of Polish and Russian consumers: are feelings and intentions related? Int Market Rev 12: 35-48.

73. Reardon J, Miller C, Vida I, Kim I (2005) The effects of ethnocentrism and economic development on the formation of brand and ad attitudes in transitional economies. Eur J Market 39: 737-754

74. Supphellen M, Gronhaug K (2003) Building foreign brand personalities in Russia: the moderating effect of consumer ethnocentrism. Int J Advertising 22: 203-226.

75. Cameron RC, Elliot GR (1998) The 'country-of-origin effect' and consumer attitudes to 'buy local' campaigns: Australian evidence. Aust Market J 6: 39-50.

76. Elliot G (2006) A less developed country perspective of consume ethnocentrism and country of origin effects: Indonesian evidence. Asia Pac J Market Logist 18: 79-92.

77. Lao A (2011) Unintended Consequences: How Pursuing Aboriginal Treaty Rights Inadvertently Strengthens Canadian Sovereignty. Trail Six: Undergraduate Geogr J 5: 57-69.

78. Huddleston P, Good LK, Stoel L (2001) Consumer ethnocentrism, product necessity and Polish consumers' perceptions of quality. Int J Retail Distrib Manage 29: 236-246.

79. Javalgi RG, Scherer RF (2005) An Application of the Consumer Ethnocentrism Model to French Consumers. Int Bus Rev 14: 325-344.

80. Chryssochoidis G, Krystallis A, Perreas P (2007) Ethnocentric beliefs and country-of-origin (COO) effect: impact of country, product and product attributes on Greek consumers' evaluation of food products. Eur J Market 41 : 1518-1544.

81. Schooler RD (1965) Product Bias in the Central American Common Market. J Market Res 2: 394-397.

82. Son J, Jin B, George B (2013) Consumers' purchase intention toward foreign brand goods. Manage Decis 51: 434-450.

83. Bruning ER (1997) Country of origin, national loyalty and product choice: the case of international air travel. Int Market Rev 14: 59.

84. Triandis HC, Leung K, Villareal MJ, Clack FL (1985) Allocentric versus idiocentric tendencies: convergent and discriminant validation. $J$ Res Personality 19: 395-415

85. Watson G, Johnson D (1972) Social Psychology: Issues and Insights, J.B Lippincott, New York, NY.

86. Ray JJ (1990) Racism, conservatism and social class in Australia: with German, Californian and South African comparisons. Personality Indiv Differ 11: 187-189.

87. Verlegh PWJ (2007) Home country bias in product evaluation: the complementary roles of economic and socio-psychological motives. J Int Bus Stud 38: 361-373

88. Kotler P (2003) Marketing Management.10th edition. Tsinghua University Press.

89. Tan CT, Farley JU (1987) The impact of cultural patterns on cognition and intention in Singapore. J Consum Res 13: 540-544.

90. Cottingham PL, Morris M (1991) Considering Japan: how black Americans view the Japanese. Survey Report of the Joint Center for Political and Economic Studies.

91. Zarkada-Fraser A, Fraser C (2002) Store patronage prediction for foreignowned supermarkets. Int J Retail Distrib Manage 30: 282-299.

92. Ettenson R, Wagner J, Gaeth G (1988) Evaluating the effect of country of origin and the 'Made in the USA' campaign: a conjoint approach. J Retailing 64: 85-100.

93. Orth UR, Firbasova Z (2003) The role of consumer ethnocentrism in food product evaluation. Agribusiness 19: 137-153. 
Citation: Tantray S (2018) Consumer Ethnocentrism in 21st Century: A Review and Research Agenda. Bus Eco J 9: 368. doi: 10.4172/21516219.1000368

94. Kwak H, Jaju A, Larson T (2006) Consumer ethnocentrism offline and online: the mediating role of marketing efforts and personality traits in the United States, South Korea, and India. J Acad Market Sci 34: 367-385.

95. Al Ganideh SF, Al Taee H (2012) Examining Consumer Ethnocentrism amongst Jordanians from an Ethnic Group Perspective. Int J Market Stud 4: $1-10$.

96. John A, Brady M (2009) The Impact of Consumer Ethnocentrism Tendencies on Buyers Evaluations of the Quality of South African Packaged and NonPackaged Consumables in Mozambique. Int J Bus Res 9: 105-114.

97. Erdogan BZ, Uzkur TC (2010) Effects of ethnocentric tendency on consumers' perception of product attitudes for foreign and domestic products. Cross Cult Manage: Int J 17: 393-406.

98. Kim S, Pysarchik DT (2000) Predicting purchase intentions for uni-national and bi-national products. Int J Retail Distrib Manage 28: 280

99. Suh T, Kwon IWG (2002) Globalization and reluctant buyers. Int Market Rev 19: $663-680$.

100. Brodowsky GH (1998) The effects of country of design and country of assembly on evaluative beliefs about automobiles and attitudes toward buying them: a comparison between low and high ethnocentric consumers. J Int Consum Market 10: 85-113.

101. Samiee S (1994) Customer evaluation of products in a global market. J Int Bus Stud 25: 579-604.

102. Yu JH, Albaum G (2002) Sovereignty change influences on consume ethnocentrism and product preferences: Hong Kong revisited one year later. J Bus Res 55: 891.

103. Evans R (2012) Chinese "Patriotic" education draws protesters in Hong Kong Business Week.

104. Insch GS, McBride JB (2004) The impact of country-of-origin cues on consumer perceptions of product quality: A binational test of the decomposed country-of-origin construct. J Bus Res 57: 256-265.
105. Jain SK, Kaur G (2006) Role of Socio-demographics in Segmenting and Profiling Green Consumers: A Study of Consumers in India. J Int Consum Market 18: 107-146.

106. Kahle LR (1983) Social Values and Social Change: Adaptation to Life in America, New York: Praeger.

107. Klein JG (2002) Us versus them, or us versus everyone? Delineating consumer a version to foreign goods. J Int Bus Stud 33: 345-363.

108. Klein JG, Ettenson R, Krishnan C (2006) Extending the construct of consumer ethnocentrism: when foreign products are preferred. Int Market Rev 23: 304-321.

109. Micken KS (1993) Materialism and the self, doctoral dissertation, Old Dominion University, Norfolk, VA.

110. Kahle LR (1985) Social values in the eighties: a special issue. Psychol Market 2: 345-363.

111. Moon BJ, Jain SC (2001) Consumer processing of international advertising: the roles of country of origin and consumer ethnocentrism. J Int Consum Market 14: 89.

112. Oh L, Zhang $Y(2010)$ Understanding Chinese users' preference for domestic over foreign Internet services. J Int Consum Market 22: 227-243.

113. Peterson RA, Jolibert AJP (1995) A meta-analysis of country-of-origin effects $J$ Int Bus Stud 26: 157-175

114. Saffu K, Walker JH (2005) An assessment of the Consumer Ethnocentric Scale (CETSCALE) in an advanced and transitional country: the case of Canada and Russia. Int J Manage 22: 556-571.

115. Strutton D, Pelton LE, Lumpkin JR (1994) Internal and external country of origin stereotypes in the global marketplace: effects and implications for the domestic promotion of US automobiles. J Global Market 7: 61-77.

116. Wall M, Heslop LA (1986) Consumer attitudes toward Canadian-made versus imported products. J Acad Market Sci 14: 27-36. 